\title{
Powassan Virus
}

National Cancer Institute

\section{Source}

National Cancer Institute. Powassan Virus. NCI Thesaurus. Code C134498.

A positive-sense single-stranded RNA virus in the genus Flavivirus. It is the causative agent of Powassan Disease, an infection of the central nervous system associated with encephalitis and/or meningitis. The virus is maintained in a cycle between ticks and smallto-medium-sized rodents. 